\title{
COUPLED HILFER AND HADAMARD RANDOM FRACTIONAL DIFFERENTIAL SYSTEMS WITH FINITE DELAY IN GENERALIZED BANACH SPACES
}

\author{
SaÏD AbBas, NASsir Al ARIFI, MOUfFAK BEnCHOHRA \\ AND JOHNNY HENDERSON
}

\begin{abstract}
This article deals with some questions of existence and uniqueness of random solutions for some coupled systems of random Hilfer and Hilfer-Hadamard fractional differential equations with finite delay. We use some generalizations of classical random fixed point theorems on generalized Banach spaces.
\end{abstract}

Mathematics subject classification (2010): 26A33.

Keywords and phrases: Fractional differential equation, left-sided mixed Riemann-Liouville integral of fractional order, left-sided mixed Hadamard integral of fractional order, Hilfer fractional derivative, Hadamard fractional derivative, Hilfer-Hadamard fractional derivative, coupled system, generalized Banach space, delay, random fixed point.

\section{REFERENCES}

[1] S. Abbas, W. Albarakati, M. Benchohra And Y. Zhou, Weak solutions for partial pettis Hadamard fractional integral equations with random effects, J. Int. Equ. Appl. 29 (4) (2017) 1-19.

[2] S. Abbas, M. Benchohra, J. R. Graef and J. Henderson, Implicit Fractional Differential and Integral Equations: Existence and Stability, De Gruyter, Berlin, 2018.

[3] S. Abbas, M. Benchohra, J. E. Lazreg And Y. Zhou, A Survey on Hadamard and Hilfer fractional differential equations: Analysis and Stability, Chaos, Solitons Fractals, 102 (2017) 47-71.

[4] S. Abbas, M. Benchohra And G. M. N'GuÉRÉKATA, Topics in Fractional Differential Equations, Springer, New York, 2012.

[5] S. AbBas, M. Benchohra And G. M. N'GuÉréKatA, Advanced Fractional Differential and Integral Equations, Nova Science Publishers, New York, 2015.

[6] S. AbBas, M. Benchohra And Y. ZHou, Coupled Hilfer fractional differential systems with random effects, Adv. Difference Equ. 2018: 369, 12 pp.

[7] G. Allaire And S. M. Kaber, Numerical Linear Algebra, ser. Texts in Applied Mathematics, Springer, New York, 2008.

[8] D. Bothe, Multivalued perturbation of m-accretive differential inclusions, Isr. J. Math. 108 (1998), 109-138.

[9] H. W. ENGL, A general stochastic fixed-point theorem for continuous random operators on stochastic domains, J. Math. Anal. Appl. 66 (1978), 220-231.

[10] K. M. FURATI AND M. D. KASSIM, Non-existence of global solutions for a differential equation involving Hilfer fractional derivative, Electron. J. Differential Equations 2013, No. 235, 10 pp.

[11] K. M. FURATI, M. D. KASSIM, AND N.-E. TATAR, Existence and uniqueness for a problem involving Hilfer fractional derivative, Comput. Math. Appl. 64 (2012), 1616-1626.

[12] J. R. Graef, J. Henderson, A. Ouahab, Some Krasnosel'skii type random fixed point theorems, J. Nonlinear Funct. Anal. 2017 (2017), 1-34, Article ID 46.

[13] R. Hilfer, Applications of Fractional Calculus in Physics, World Scientific, Singapore, 2000.

[14] S. IтOH, Random fixed point theorems with applications to random differential equations in Banach spaces, J. Math. Anal. Appl. 67 (1979), 261-273. 
[15] R. KAMOCKI AND C. OBCZŃNSKI, On fractional Cauchy-type problems containing Hilfer's derivative, Electron. J. Qual. Theory Differ. Equ., 2016, No. 50, 1-12.

[16] A. A. Kilbas, Hadamard-type fractional calculus, J. Korean Math. Soc. 38 (6) (2001) 1191-1204.

[17] A. A. Kilbas, H. M. SRivastava And J. J. Trujillo, Theory and Applications of Fractional Differential Equations, Elsevier Science B. V., Amsterdam, 2006.

[18] L. LiU, F. GUO, C. WU AND Y. WU, Existence theorems of global solutions for nonlinear Volterra type integral equations in Banach spaces, J. Math. Anal. Appl. 309 (2005), 638-649.

[19] K. LiU, J. R. WANG AND D. O'Regan, Ulam-Hyers-Mittag-Leffler stability for $\psi$-Hilfer delay differential equations, Adv. Difference Equ. 2019: 50, 12 pp.

[20] I. R. Petre And A. Petrusel, Krasnoselskii's theorem in generalized Banach spaces and applications, Electron. J. Qual. Theory Differ. Equ. (2012), No. 85, 20 pp.

[21] M. D. QASSIM, K. M. FuRATI, AND N.-E. TATAR, On a differential equation involving HilferHadamard fractional derivative, Abstract Appl. Anal., vol. 2012, Article ID 391062, 17 pages, 2012.

[22] M. D. QASSIM AND N.-E. TATAR, Well-posedness and stability for a differential problem with HilferHadamard fractional derivative, Abst. Appl. Anal. Volume 2013, Article ID 605029, 12 pages, 2013.

[23] S. G. Samko, A. A. Kilbas And O. I. Marichev, Fractional Integrals and Derivatives. Theory and Applications, Gordon and Breach, Amsterdam, 1987, Engl. Trans. from the Russian.

[24] M. L. Sinacer, J. J. Nieto And A. OuAhab, Random fixed point theorems in generalized Banach spaces and applications, Random Oper. Stoch. Equ. 24 (2016), 93-112.

[25] V. E. Tarasov, Fractional Dynamics: Application of Fractional Calculus to Dynamics of Particles, Fields and Media, Springer, Heidelberg; Higher Education Press, Beijing, 2010.

[26] Ž. Tomovski, R. Hilfer AND H. M. SRIVAStaVA, Fractional and operational calculus with generalized fractional derivative operators and Mittag-Leffler type functions, Integral Transform. Spec. Funct. 21 (11) (2010), 797-814.

[27] R. S. VARGA, Matrix iterative analysis, Second revised and expanded edition, Springer Series in Computational Mathematics, 27, Springer-Verlag, Berlin, 2000.

[28] J.-R. WANG, AND Y. Zhang, Nonlocal initial value problems for differential equations with Hilfer fractional derivative, Appl. Math. Comput. 266 (2015), 850-859.

[29] Y. Zhou, J.-R. WAng, L. Zhang, Basic Theory of Fractional Differential Equations, Second edition, World Scientific Publishing Co. Pte. Ltd., Hackensack, NJ, 2017. 